\title{
Antioxidant capacity, oxidative stability of mango (Mangifera indica L) seed oil in 2 varieties and two degrees of maturity
}

\section{Capacidad antioxidante y estabilidad oxidativa del aceite de semilla de mango (Mangifera indica L) en dos variedades y dos grados de madurez}

\author{
Elza Berta Aguirre $\operatorname{Vargas}^{1}$, María de Fátima Arévalo Oliva ${ }^{1}$, Magda Isabel Javier Villanueva ${ }^{1}$ and \\ Gilbert Rodriguez-Paucar ${ }^{l}$ \\ ${ }^{1}$ Universidad Nacional del Santa, Perú.
}

\begin{abstract}
The present work search the influence of the Edward and Kent mango varieties, in degrees of maturity partially ripe and ripe respectively, on the antioxidant capacity and oxidative stability of mango seed oil (Mangifera indica L.), previously extracted by pressing in cold, clarified by centrifugation, and stored in refrigeration under nitrogen atmosphere. The antioxidant capacity is determine by DPPH method, the oxidative stability by the Rancimat test with temperature parameters 130,140 and $150{ }^{\circ} \mathrm{C}$, and airflow $15 \mathrm{~L} / \mathrm{h}$. The results are evaluate by ANOVA $(\mathrm{p}<0,05)$ finding in the antioxidant capacity and other analyzes made a significant difference with a level of $95 \%$ confidence in the variables of variety and degree of maturity. Regarding the influence, the relationship will be determined that in a mature degree of maturity has a higher content of unsaturated fatty acids (oleic), and a lower content of total polyphenols, antioxidant capacity and oxidative stability. Being the oil of the variety Edward in degree of maturity ripe the most stable due to low value of the peroxide index $(0,898$ meq $\mathrm{O} 2 / \mathrm{kg})$, acidity $(1,1856 \%)$, and the higher content of total polyphenols $(8,5931 \mathrm{mg} \mathrm{GAE} / 100 \mathrm{~g})$ and antioxidant capacity $(263,858$ umoltrolox $/ 100 \mathrm{~g})$, with a lifetime of 12,89 years.
\end{abstract}

Keywords: Mango (Mangifera indica L.), mango seed, oil, variety, degree of maturity.

\section{RESUMEN}

El presente trabajo investiga la influencia de las variedades de mango Edward y Kent, en grado parcialmente maduro y en madurez total, sobre la capacidad antioxidante y estabilidad oxidativa del aceite de semilla de mango (Mangifera indica L.), previamente extraído por prensado en frío, clarificado por centrifugación, y almacenado en refrigeración bajo atmósfera de nitrógeno. La capacidad antioxidante se determina mediante el método DPPH, la estabilidad oxidativa mediante la prueba de Rancimat con parámetros de temperatura 130,140 y $150{ }^{\circ} \mathrm{C}$ y caudal de aire de $15 \mathrm{~L} / \mathrm{h}$. Los resultados son evaluados por

Elza Berta Aguirre Vargas. ORCID: https://orcid.org/0000-0003-1659-9874 email: eaguiire@uns.edu.pe

María de Fátima Arévalo Oliva. ORCID: https://orcid.org/0000-0003-3432-9843 email: 201335034@uns.edu.pe

Magda Isabel Javier Villanueva. ORCID: https://orcid.org/0000-0002-5673-0446 email: magda.javi@hotmail.com

Gilbert Rodriguez-Paucar. ORCID: https://orcid.org/0000-0003-2981-1213 email: grodriguez@uns.edu.pe 
ANOVA $(\mathrm{p}<0,05)$ encontrando en la capacidad antioxidante y otros análisis registrando una diferencia significativa con un nivel de confianza del $95 \%$ en variedad y grado de madurez. En cuanto a la influencia, se determinará la relación que en plena madurez presenta un mayor contenido de ácidos grasos insaturados (oleico), y un menor contenido de polifenoles totales, capacidad antioxidante y estabilidad oxidativa. El aceite de la variedad Edward totalmente maduro es más estable, debido al bajo valor del índice de peróxido $(0,898 \mathrm{meq} \mathrm{O} 2 / \mathrm{kg})$, acidez $(1,1856 \%)$, y mayor contenido de polifenoles totales $(8,5931 \mathrm{mg}$ $\mathrm{GAE} / 100 \mathrm{~g})$ y capacidad antioxidante $(263.858 \mathrm{umol}$ trolox/100g), con una vida útil de 12,89 años.

Palabras clave: Mango (Mangifera indica L.), semilla de mango, petróleo, variedad, grado de madurez.

\section{INTRODUCTION}

$\mathrm{F}$ ood and Agriculture Organization of the United Nations FAO (2017) defines mango (Mangifera indica L.) as one of the most important tropical fruits due to the growing demand by consumers, resulting in a maximum growth of 47 million metric tons in 2016 in world production. This may be due to its attributes of sensory quality and nutritional value. In Peru, mango is one of the main export fruits, according to INEI (2015) reports that mango is in the top 5 most cultivated and exported fruits, being the Piura region who has a total of 27,120 hectares of mango cultivated area, covering $78 \%$ of the fruit's production, the Lambayeque region is next with $12 \%$, and Ancash with $10 \%$.

Guerrero et al (2012) identified the Red varieties as the main ones in Peru, being the Kent variety in the fresh state most commercial in export, followed by Edward and Tommy Atkins varieties. These varieties are required in two sectors of the mango industry, primary sector (sale of fresh mango) and secondary sector (preparation and packaging of mango). The IQF frozen mango industry is located in this last sector, with brix degrees between 11 to $14^{\circ} \mathrm{Bx}$, known as degree of maturity partially ripe; and the pulping industry, which includes syrups, jams, nectars, among others, with brix degrees of $15^{\circ} \mathrm{Bx}$ or more, known as degree of maturity ripe.

Rodríguez (2014) reports that in the industrialization of mango only the pulp is used, generating a large volume of waste in the process ( $40 \%$ to $60 \%$ approx.) that is the byproducts such as husk and seed are discarded, thrown into landfills. This fact increasing environmental pollution due to the high concentrations of residual phenolic compounds that these by-products contain, which could inhibit seed germination.

Rodríguez (2014) also points out that the mango peel can be required to extract pectin, enzymes, or as flour for baking and biscuits; and that, the mango seed contains great antioxidant components and oil inside. Culebro (2017) indicates that the seed compared to the peel, occupies a greater volume in the mango of $10-50 \%$ of the fruit weight, while the peel of $15-20 \%$. This seed contains an almond inside, which represents $45-75 \%$ of the entire seed. It was the object of study in this investigation.

Kittiphoom and Sutasinee (2013) found oil in the mango seed, which can be edible, and it can be required in confectionery, cosmetics, soap making, or as a substitute for cocoa fat in the production of chocolates, due the pleasant aroma of the oil and its composition in fatty acids.

Tapia et al (2013) point out that the lipid profile of mango seed makes it have significant marketing potential, and thus obtain economic resources from an undervalued agro industrial residue.

There are studies on the characterization of mango seed oil as the aforementioned authors, but until now, a comparison research between varieties and degrees of maturity has not were established. That is why the main objective was set to determine the influence of Edward and Kent mango varieties in the degrees of maturity partially ripe and ripe respectively on the physicochemical characteristics and oxidative stability of mango seed oil. Likewise, estimate the content of total polyphenols, antioxidant capacity, and its fatty acid profile. In addition, complementary tests to evaluate which type of oil is the most stable and thus achieve in this way to identify if the variables variety and degree of maturity are significant in the characterization of mango seed oil. In order to determine with which industry a greater benefit from mango seed, and thus reduce the environmental impact of this by-product that are generated in large volumes.

\section{Materials AND Methods}

\section{Raw material}

Mango seeds from the north of the country, of two varieties: Kent and Edward, and two degrees of maturity were used: partially ripe ( $\left(11\right.$ to $\left.14^{\circ} \mathrm{Bx}\right)$ and ripe $\left(15^{\circ} \mathrm{Bx}\right.$ or more), collected from the company Inversiones Frigorificas PRC SAC, located in the Santa district, Ancash.

\section{Proximal analysis for mango seed almond}

The humidity of the mango seed almonds of both varieties and degrees of maturity was analyzed according to the drying method in the stove (brand: Pol-Eko Aparature, model: SW 17TC, and series: SW-199) by difference of pesos as established in AOAC 934.06 (37.1.10). The ashes of the samples were determined by incinerating the organic matter at $650^{\circ} \mathrm{C}$ for 3 hours in the muffle (brand: Thermolyne, series: 347034984) according to AOAC 942.05. Finally the percentage of fats was analyzed according to the provisions of AOAC 922.06 (32.1.14), in the sox let fat extractor (brand: Foss, model: Soxtec TM-2043) using petroleum ether as a solvent.

\section{Production of mango seed oil}

Mango seeds in different crates, classified according to the degree of maturity and variety, were received at the IITA (Institute of Agro Industrial Technological Research) located at the National University Santa. They were stored in refrigeration at $4^{\circ} \mathrm{C}$ until processing in less than 24 hours; subsequently, the seeds were washed in tubs with water to remove any traces of mango pulp that has been impregnated 
externally, and they were dried by means of solar exposure in the afternoon to facilitate the extraction of the almonds. The almonds are extracts from the seeds manually, and then we separated the almonds from their cotyledons, dark layer that surrounds the almonds.

Then the whole almonds are dries in an oven at a temperature of $60^{\circ} \mathrm{C}$, until reaching a humidity of $8 \% \pm 0$, $03 \%$, the time will depend on the initial humidity of the mango seed almond. Successively they were fractionated in a mill manual until obtaining grains between $0,85 \mathrm{~mm}$ and 2 $\mathrm{mm}$, and they went through a sieving to ensure that only the grains. Mechanical extraction is carry out in an expeller press (model Komet CA 59G). A 4 mm nozzle size is used, and a worm speed of rotation of $15 \mathrm{rpm}$ at a temperature not more than $50^{\circ} \mathrm{C}$. The oil extracted from each variety and degree of maturity was subjected to a centrifugation process at $3600 \mathrm{rpm}$ for a time of 10 minutes, lastly the centrifuged oil was packaged in amber screw-top containers, under a nitrogen atmosphere and stored in refrigeration at $4 \pm 1{ }^{\circ} \mathrm{C}$.

\section{Physicochemical characteristics of mango seed oil}

The relative density value is calculus using the pycnometer method according to the IUPAC 2.101 method. The refractive index was calculated using the digital refract-meter (brand: Rudolph Research, model: J-157, and series: 14265) according to the method given by AOCS Cc-7-25. The acid number is calculus by titration according to the method described in AOCS Cd 3d-63. The peroxide value is calculus by titration according to the AOCS Cd $8 b-90$ method. The iodine number was determined using the hanus: chloroform method established by AOAC 920,158. The anisidine index was calculated by measuring absorbance on the UV VISIBLE digital spectrophotometer (brand: Jasco, model: V670) according to the AOCS Cd 18-90 method. The total oxidation value (Totox) was calculated according to what was stated by (Shahidi and Wanasundara 2008) as Totox $=(2 x P V)$ $+\mathrm{p}-\mathrm{AnV}$.

\section{Fatty acid profile}

The fatty acid profile of mango seed oils was determined according to what was stated in the official method AOAC 996.06, using the Shimadzu brand gas chromatography equipment; model GC-2010, equipped with a flame ionization detector (FID) at a temperature of $200^{\circ} \mathrm{C}$, and a Shimadzu AOC20Si automatic sampler. A SP Rt'TM -2560 silica capillary column $(100 \mathrm{~m} \times 0,25 \mathrm{~mm}$ with $0,25-\mu \mathrm{m}$ film $)$ helium is required as the carrier gas at a flow rate of 124, 2 $\mathrm{ml} / \mathrm{min}$ and pressure of $261,5 \mathrm{kPa}$. The injection volume was $1 \mu \mathrm{l}$. The fatty acid methyl esters were prepared according to the Fames method, AOAC 991.39. Weigh 0,025 $\mathrm{g}$ of oil, add $1,5 \mathrm{ml}$ of $\mathrm{NaOH} 0,5 \mathrm{~N}$, and place in a water bath (brand: Aqua Bath, model: No. 18007 A-1 CEC) for 5 minutes. Cool to a temperature of $30^{\circ} \mathrm{C}$ and proceed to add 2 $\mathrm{ml}$ of boron trifluoride (BF3), placing in a water bath for 30 minutes, again cool and add $1 \mathrm{ml}$ of isooctane, add $5 \mathrm{ml}$ of saturated $\mathrm{NaCl}$ solution, and separate the organic phase in amber vials, all with stirring and constantly adding nitrogen.

\section{Determination of total phenolic compounds}

The method established by Bail et al. (2008) is applies for sample preparation. Of each oil sample, $1 \mathrm{~g}$ are weighed into each test tube, $3 \mathrm{ml}$ of methanol: water solution (90: 10of each oil sample $1 \mathrm{~g}$ was weighed into each test) was added. Then shake for 4 minutes in the vortex, it was placed in the centrifuge (brand: Sigma, model: 2-6) for 5 minutes at 3000 rpm per minute, the extraction procedure was repeated 3 times for each oil, all the methanol extracts, and concentrated to dryness by adding nitrogen. If the sample must be stored, store in the dark at $20^{\circ} \mathrm{C}$ until analysis, and when the procedure is to continue, dissolve the dry matter of the sample with $1 \mathrm{ml}$ of methanol: water (10:90). The method established by (Folin and Ciocalteu 1927) is follow to determine the amount of total polyphenols in the samples. The standard curve must first be prepared, and for this $900 \mu \mathrm{l}$ of each extract is take from the samples and placed in glass tubes lined with aluminum or amber. Adding $300 \mu \mathrm{l}$ of Folin-Denis solution in each glass tube, stirring in the vortex for 3 minutes, and standing for 5 minutes $150 \mu$ of sodium carbonate was added, stir in the vortex for 3 minutes, and make up to a volume of $3750 \mu \mathrm{l}$ with distilled water. Shake for 3 minutes until homogenized. Then let the samples stand for 5 minutes, and the samples were read on the UV - visible digital spectrophotometer (brand: Jasco, model: V-670) at $726 \mathrm{~nm}$. The results is express in $\mathrm{mg}$ Gallic acid (GAE)/g sample.

\section{Determination of antioxidant capacity}

Antioxidant capacity was determined using the DPPH colorimetric method, applying the methodology established by Plank et al (2012), whose method is valid by the international AOAC. For the preparation of the extract of the oil samples, the procedure established by Bail et al (2008) already explained in the determination of total phenolic compounds, where in general terms methanol is add, it went through agitation and centrifugation.

The determination of the antioxidant capacity must be carry out by first preparing the standard trolox curve and thus being able to read the samples. For this, the methodology proposed by Plank et al (2012) which consists of taking $100 \mu \mathrm{l}$ of each oil sample, placing them in glass tubes lined with aluminum, and adding $6,25 \mathrm{ml}$ of DPPH solution, covering the tubes, shaking until homogeneous, and incubating on ultrasound (mark: Cole Parmer, model: 8892-26) at $37^{\circ} \mathrm{C}$ for 2 hours. After the time, remove the tubes, and finally perform the reading on the UV-visible digital spectrophotometer (brand: Jasco, model: V-670) at $517 \mathrm{~nm}$, using blank for the sample. The results is express in $\mu \mathrm{g}$ Trolox/g sample.

\section{Oxidative stability}

The oxidative stability index (OSI) in hours was determined using the Rancimat equipment (Metrohm brand, model $743 \Omega$, Switzerland), using the AOCS Cd 12b-92 method. Consisting of weighing 3,0 0 , $1 \mathrm{~g}$ of each oil sample in reaction tubes. These tubes are place in a heating block at temperatures 130,140 and $150^{\circ} \mathrm{C}$. High temperatures were chosen because tests were carried out previous where at low temperatures it required a long time of analysis, and due to the composition of the almond oil of the mango seed, which is rich in saturated and unsaturated fatty acids, such as stearic 
ISSNe: 2617-9156

and oleic acid (Abdel et al., 2012). Above the reaction tubes an air flow at $15 \mathrm{~L} / \mathrm{h}$ bubbles, the volatile organic acids that dissipate in the sample tube are received in polycarbonate glasses previously filled with $60 \mathrm{ml}$ of distilled water, the conductivity $(\mu \mathrm{S} / \mathrm{cm})$ of the water was continuously recorded.

\section{Useful life}

The shelf life was estimated using the extrapolation method at the storage temperature of $20^{\circ} \mathrm{C}$, establishing a mathematical relationship between the OSI values and the temperatures used in the Rancimat equipment (130, 140 and $150^{\circ} \mathrm{C}$ ), for vegetable oils. In the mathematical formula, the value $\mathrm{A}$ is the temperature coefficient. It is obtain by the slope of the lines that is make in the curves of the conductivity us time graph. This value indicates how susceptible the oil is to temperature rise. Constant $\mathrm{B}$ is an empirical value, without physical significance (Villanueva, 2013).

$$
\log (\mathrm{OSI})=\mathrm{A}+\mathrm{BT}
$$

\section{Statistical design}

The statistical design is valued in two groups, according to the statistical variables that influence the analysis.

Two statistical programs is required for the evaluation of the data. For the evaluation of the proximal and physicochemical analyzes, as well as the profile of fatty acids, total polyphenols and antioxidant capacity, analysis of variance, Duncan test and standard deviation of the replicas and repetitions were applied using a simple model, since the variables are degrees of maturity and variety.

The Completely Random Design (DCA) was used to evaluate the oxidative stability index of mango seed oil, with a factorial arrangement of $2 \times 2 \times 3=12,2$ varieties of mango, 2 degrees of maturity, and 3 temperatures (Rancimat parameter), that is, 12 treatments with 3 repetitions.

Being 36 runs that are statistically value for the data. They are subject to a completely random design. Whose statistical model is based on the calculation of the estimate of the useful life because of the effect of the interactions between all the variables as well as variety (Kent, and Edward), degree of maturity (partially ripe and ripe), and temperature (130, 140 and $150^{\circ} \mathrm{C}$ ) including experimental random error.

\section{RESUltS}

\section{Classification and characterization of mango}

A sampling of different mango boxes from the city of Chulucanas - Piura is carry out. Mangoes that enter the process (degree of maturity partially ripe) for chunks, and those that enter for pulp (degree of maturity ripe) in the Edward and Kent variety, at the company Inversiones Frigoríficas PRC S.A.C.

It is morphologically according to color and size, and it is physically character according to the weights of the fruit parts as shown in Table 1. In addition, finding a lightweight in the fruit between 368 to $418 \mathrm{~g}$, and proportions of seed to mango fruit between 6 to $8 \%$ in all samples.

Lieb et al (2018) reported fruit weight between 351 to 659 $\mathrm{g}$ and seed to fruit weight between $4,9 \%$ to $12 \%$. Also states that the morphological characteristics of the fruit in general there is no correlation between seed - fruit and grain- seed, but that in turn a low ratio of almond to seed makes the extraction of fat from mango almond inefficient.

Table 1.

Physical characterization of the mango variety Edward and Kent in the two degrees of maturity

\begin{tabular}{|c|c|c|c|c|c|}
\hline \multirow{2}{*}{\multicolumn{2}{|c|}{$\begin{array}{r}\text { Variety } \\
\text { Degree of maturity }\end{array}$}} & \multicolumn{2}{|r|}{ Edward } & \multicolumn{2}{|r|}{ Kent } \\
\hline & & Partially ripe & Ripe & Partially ripe & Ripe \\
\hline \multicolumn{2}{|c|}{ Total Soluble Solids (T.S.S.) } & $11-14^{\circ}$ Brix & $\geq 15^{\circ}$ Brix & $11-14^{\circ}$ Brix & $\geq 15^{\circ}$ Brix \\
\hline FRUIT & Fruit weight (g) & $\begin{array}{l}368,4 \pm \\
54,9758^{*}\end{array}$ & $395,8 \pm 20,5663^{*}$ & $414,5 \pm 51,0288^{*}$ & $417,4 \pm 62,7995^{*}$ \\
\hline SHELL & Shell weight (g) & $48,6 \pm 12,5958^{*}$ & $40,1 \pm 3,5553^{*}$ & $50,8 \pm 9,5088^{*}$ & $55,5 \pm 8,4528^{*}$ \\
\hline \multirow[b]{2}{*}{ PULP } & Shell percentage $(\%)$ & $13,0 \pm 1,8047^{*}$ & $10,2 \pm 1,2079^{*}$ & $12,4 \pm 3,1348^{*}$ & $13,3 \pm 0,5905^{*}$ \\
\hline & Pulp weight (g) & $\begin{array}{l}254,9 \pm \\
20,7445^{*}\end{array}$ & $266,8 \pm 37,5824^{*}$ & $297,3 \pm 36,8612^{*}$ & $299,5 \pm 56,8487^{*}$ \\
\hline \multirow{3}{*}{ SEED } & Pulp percentage $(\%)$ & $69,8 \pm 7,0976^{*}$ & $67,2 \pm 6,2181^{*}$ & $71,7 \pm 2,5376^{*}$ & $71,5 \pm 2,9773^{*}$ \\
\hline & Seed weight (g) & $22,7 \pm 4,9244^{*}$ & $26,6 \pm 3,3045^{*}$ & $32,8 \pm 2,4171^{*}$ & $35,8 \pm 2,9009^{*}$ \\
\hline & Seed percentage $(\%)$ & $6,2 \pm 1,2191^{*}$ & $6,7 \pm 0,6864^{*}$ & $7,9 \pm 1,1160^{*}$ & $8,8 \pm 1,5481^{*}$ \\
\hline \multirow{2}{*}{ COTYLEDON } & Cotyledon weight (g) & $1,0 \pm 0,1732 *$ & $1,2 \pm 0,1000^{*}$ & $1,3 \pm 0,3594^{*}$ & $1,2 \pm 0,3304^{*}$ \\
\hline & Cotyledon perc $(\%)$ & $0,2 \pm 0,0288^{*}$ & $0,3 \pm 0,0314^{*}$ & $0,3 \pm 0,0915^{*}$ & $0,2 \pm 0,0489^{*}$ \\
\hline \multirow{2}{*}{ KERNEL } & Kernel weight (g) & $18,4 \pm 0,3215^{*}$ & $18,6 \pm 0,5033^{*}$ & $20,9 \pm 0,8770^{*}$ & $25,3 \pm 2,6589^{*}$ \\
\hline & Kernel perc (\%) & $4,1 \pm 0,7569^{*}$ & $4,7 \pm 0,2478^{*}$ & $5,1 \pm 0,6525^{*}$ & $6,2 \pm 1,1883^{*}$ \\
\hline
\end{tabular}


ISSNe: 2617-9156

The results also agreed with what are state by (Garrido and Valdés, 2012) where the peel constitutes approximately between $15-20 \%$ of the fruit, while the seeds represent 20 $60 \%$ of the weight of the whole fruit, depending on the mango variety and the inner nucleus of the seed of $45-75 \%$ with respect to the whole seed.

The importance of characterizing the fruit lies in knowing its morphological characteristics to know the genetic differences between each variety and degree of maturity to know the influence of these characteristics on the appearance of the fruit (López, 2013).

It is know that the mango presents variability in its morphological characteristics depending on the place where it is groans, since the fruit couple's information that are produced in the interaction with the environment in its genomes, according to the needs it requires to survive in its environment (López, 2013).

\section{Proximal characterization of the mango seed almond}

The almonds after being extract from the mango seeds are analyze proximally in both Edward and Kent varieties, and in the degrees of maturity partially ripe and ripe, the results are express in Table 2 .

The difference between the values found may be due to factors such as mango variety, climate, growing area, harvest time, or degree of fruit maturity. Knowing the humidity values is an important factor that affects the quality of the mango seed almond (Ashoush and Gadallah 2011).

The ash content is relate to the total mineral content present in the mango almond. Allowing know the presence of inorganic elements in the mango seed almond, knowing this is useful to know if the mango seed almond can be used to produce other co-products that generate added value, such as fertilizer for the soil or for animal feed due to the mineral content (Abdelaziz, 2018).

The percentage of fats is important since from an industrial point of view the highest percentage is sought, and according to table 2, the Edward variety in both varieties reported a higher percentage of fats, and a pattern was observed that the lower the degree of maturity, the lower the percentage of fats. The existing differences come from the harvest of the fruit since the varieties are very different morphologically and genetically (López, 2013).

\section{Table 2.}

Proximal chemical composition of mango seed

\begin{tabular}{ccccc}
\hline Variety & Degree of maturity & Humidity (\%) & Ashes (\%) & Fat percentage (\%) \\
\hline Edward & Partially ripe & $51,5633 \pm 0,7586^{*}$ & $2,7867 \pm 0,2914^{*}$ & $10,2158 \pm 0,4624^{*}$ \\
& Ripe & $44,8500 \pm 0,3604^{*}$ & $3,4633 \pm 0,1401^{*}$ & $11,0282 \pm 0,7351^{*}$ \\
& Partially ripe & $60,0033 \pm 0,7697^{*}$ & $2,0367 \pm 0,1150^{*}$ & $8,6576 \pm 1,9786^{*}$ \\
& Ripe & $55,5067 \pm 1,2152^{*}$ & $2,4067 \pm 0,1550^{*}$ & $9,1553 \pm 1,6883^{*}$ \\
\hline
\end{tabular}

* Data expressed as mean \pm standard deviation of 2 replicates including 3 replicates each.

\section{Extraction of mango seed oil}

The percentage yield in Edward variety mango seed oil in degrees of maturity, partially ripe and ripe extracted by cold pressing had values of $10,6567 \% \pm 0,1901^{*}$ and $11,1367 \% \pm$ $0,0907 *$ respectively; and for the Kent variety in degrees of maturity, partially ripe and ripe, the values were $7,7967 \% \pm$ $0,1332 *$ and $8,5567 \% \pm 0,1823 *$ respectively.

Jahurul et al (2014) found 11,29\% yield values for Water Lily variety mango almond oil extracted with supercritical fluids (CO2); Sikdar et al (2017) found a yield of 17,3ml of oil for every $1 \mathrm{~kg}$ of mango almond oil by solvent extraction by sox let. Nadeem et al (2016) found values of 10, $2 \%$ in obtaining mango almond oil by sox let extraction. Rodríguez (2014) mentions that mango almond oil yields a higher yield through solvent extraction, reaching values of more than $12 \%$, while in mechanical methods it has a yield of around 8 to $10 \%$.

This may be because in the extraction the cake that comes out as residue still contains oil, decreasing the extraction performance, but with mechanical methods there is no solvent contamination in the oil as this is $100 \%$ pure, and an oil refining operation that reduces the amount would no longer be necessary (Rodríguez, 2014).

\section{Analysis of mango seed almond oil}

Mango almond oil of each variety and degree of maturity was physicochemical characterized, reporting the values for each analysis in Table 3. Comparing with the scientific literature on the values of relative density, López (2013) evaluated the oil of 20 varieties of mango combining two processes in extraction, with enzymes and pressing, and obtained a density of $0,9082 \mathrm{~g} / \mathrm{cm} 3$ for the Edward variety, and for the rest of varieties the relative densities are in the range of: $0,9057 \mathrm{~g} / \mathrm{cm} 3-0,9119 \mathrm{~g} / \mathrm{cm} 3$.

Finding these values very close to what are obtain in this investigation. Furthermore, each type of oil has a unique density depending on the composition of the fatty acids in the oil (Guerrero et al, 2012). 
Table 3.

Physicochemical characterization of mango seed oil

\begin{tabular}{|c|c|c|c|c|c|c|c|c|c|c|}
\hline Variety & $\begin{array}{c}\text { Degree } \\
\text { of } \\
\text { maturity }\end{array}$ & $\begin{array}{l}\text { Density } \\
(\mathrm{g} / \mathrm{cm} 3)\end{array}$ & $\begin{array}{l}\text { Refractive } \\
\text { index }\end{array}$ & $\begin{array}{l}\text { Acidity } \\
\text { index } \\
(\%)\end{array}$ & $\begin{array}{c}\begin{array}{c}\text { Peroxide } \\
\text { index }\end{array} \\
\text { (meqO2/Kg) }\end{array}$ & $\begin{array}{l}\text { Iodine } \\
\text { index } \\
\text { (cg I2/g } \\
\text { sample) }\end{array}$ & $\begin{array}{l}\begin{array}{c}\text { Anisidine } \\
\text { index }\end{array} \\
\text { (meqO2/Kg) }\end{array}$ & $\begin{array}{l}\text { Totox value } \\
(\mathrm{meqO} / \mathrm{Kg})\end{array}$ & $\begin{array}{c}\text { Antioxidant } \\
\text { capacity } \\
\text { (umolTrolox/ } \\
100 \mathrm{~g})\end{array}$ & $\begin{array}{c}\begin{array}{c}\text { Total } \\
\text { polyphenols } \\
\text { (mgGAE/ }\end{array} \\
\text { 100g) }\end{array}$ \\
\hline \multirow{2}{*}{ Edward } & $\begin{array}{l}\text { Partially } \\
\text { ripe }\end{array}$ & $\begin{array}{c}0,9053 \\
\pm \\
0,0006^{*}\end{array}$ & $\begin{array}{l}1,4561 \pm \\
0,0004^{*}\end{array}$ & $\begin{array}{c}1,1856 \\
\pm 0,08^{*}\end{array}$ & $\begin{array}{l}0,898 \pm \\
0,0317^{*}\end{array}$ & $\begin{array}{c}22,8227 \\
\pm \\
0,2507 *\end{array}$ & $\begin{array}{c}0,2967 \pm \\
0,0223^{*}\end{array}$ & $\begin{array}{c}2,0917 \pm \\
0,0411^{*}\end{array}$ & $\begin{array}{c}263,858 \pm \\
0,0890^{*}\end{array}$ & $\begin{array}{c}8,5931 \pm \\
0,7071^{*}\end{array}$ \\
\hline & Ripe & $\begin{array}{c}0,9103 \\
\pm \\
0,0016^{*}\end{array}$ & $\begin{array}{c}1,4592 \pm \\
0,0005^{*}\end{array}$ & $\begin{array}{c}1,4813 \\
\pm \\
0,0602 *\end{array}$ & $\begin{array}{l}1,066 \pm \\
0,0158^{*}\end{array}$ & $\begin{array}{c}23,4772 \\
\pm \\
0,0692 *\end{array}$ & $\begin{array}{c}0,3773 \pm \\
0,0274^{*}\end{array}$ & $\begin{array}{c}2,5089 \pm \\
0,059^{*}\end{array}$ & $\begin{array}{c}172,4238 \pm \\
0,4290^{*}\end{array}$ & $\begin{array}{c}6,2499 \pm \\
0,0579 *\end{array}$ \\
\hline \multirow{2}{*}{ Kent } & $\begin{array}{l}\text { Partially } \\
\text { ripe }\end{array}$ & $\begin{array}{c}0,9072 \\
\pm \\
0,0009 *\end{array}$ & $\begin{array}{l}1,4568 \pm \\
0,0006^{*}\end{array}$ & $\begin{array}{c}1,3976 \\
\pm \\
0,0999 *\end{array}$ & $\begin{array}{c}0,987 \pm \\
0,0160^{*}\end{array}$ & $\begin{array}{c}23,3804 \\
\pm \\
0,1006^{*}\end{array}$ & $\begin{array}{c}0,3846 \pm \\
0,0367^{*}\end{array}$ & $\begin{array}{c}2,3592 \pm \\
0,0687^{*}\end{array}$ & $\begin{array}{c}255,2214 \pm \\
0,1319^{*}\end{array}$ & $\begin{array}{c}7,7867 \pm \\
0,3291 *\end{array}$ \\
\hline & Ripe & $\begin{array}{c}0,9155 \\
\pm \\
0,0012 *\end{array}$ & $\begin{array}{l}1,4642 \pm \\
0,0010^{*}\end{array}$ & $\begin{array}{c}1,6789 \\
\pm \\
0,1397 *\end{array}$ & $\begin{array}{l}1,251 \pm \\
0,0555^{*}\end{array}$ & $\begin{array}{c}24,3053 \\
\pm \\
0,0855^{*}\end{array}$ & $\begin{array}{c}0,5982 \pm \\
0,0944^{*}\end{array}$ & $\begin{array}{c}3,0999 \pm \\
0,2053^{*}\end{array}$ & $\begin{array}{c}153,9673 \pm \\
0,0398^{*}\end{array}$ & $\begin{array}{c}5,1063 \pm \\
0,2638^{*}\end{array}$ \\
\hline
\end{tabular}

* Data expressed as mean \pm standard deviation of 2 replicates including 3 replicates each.

Regarding the refractive index Muchiri et al (2012) found values from 1,4562 to 1,4597 , and Silva (2018) obtained a refractive index of 1,461 for Kent variety mango almond oil, these values coinciding with that obtained in the Kent variety and degrees of maturity partially ripe and ripe. Silva (2018) tells us that the refractive index in oils and fats is very important, since this value is link to the unsaturation of fatty acids, increasing as the degree of unsaturation and the percentage of unsaturated acids increases, as well as the increase in the molecular weight of fatty acids.

For the acidity index, the authors (Matos and Pirela, 2014), Silva (2018), and López (2013), who obtained values of $1,26 \%, 1,4 \%$, and $1,832 \%$ in the Tetenene, Kent, and Edward respectively, also higher values reported by the authors (Rojas and Burbano 2011) and Rodríguez (2014) who obtained values of $5 \%$, and $7 \%$ in the variety Tommy Atkins and Kala Alphonso respectively. The values obtained in this investigation are in the range allowed by the Codex Stan 2101999 for cold-pressed vegetable oils and fats that mention a value of $4 \mathrm{mgKOH} / \mathrm{g}$. Furthermore, when compared to the Codex Stan 86-1981 cocoa fat standard, it allows an acid content of no more than $1,75 \%$, it could be used as an ingredient for the manufacture of chocolate and chocolate products, and allows direct use in the food industry without the need for neutralization.

Regarding the peroxide index, it is observe that values are obtain in the range of $0,8980 \mathrm{meqO} 2 / \mathrm{Kg}-1,2510 \mathrm{meqO} 2 / \mathrm{Kg}$ for mango almond oil in the Edward and Kent variety. Besides, in degrees of maturity partially ripe and ripe, these values do not exceed the value established by the Codex Stan 2010-1999 for cold pressed vegetable oils of up to a maximum of 15 meqO2/Kg. The Codex Stan 86-1981 establishes a maximum value for cocoa fat of up to 3 meqO2/Kg, with mango seed in both varieties and degrees of maturity below, which indicates good quality of the oil. Zambrano et al. (2017) reported a peroxide value of 1,278 meqO2/Kg in mango almond oil by solvent extraction, and Masud et al (2017) established values of $1,83 \mathrm{meqO} 2 / \mathrm{Kg}$ and $2,35 \mathrm{meqO} / \mathrm{Kg}$ for Arumanis variety mango almond oil extracted with two different types of solvent, hexane and ethanol respectively.

These values are slightly higher than the values obtained in both varieties and degrees of maturity. (Kittiphoom and Sutasinee 2013) establish that mango oil has a low peroxide value compared to other vegetable oils; this can be attribute to the existence of a higher concentration of phenols and a balanced composition of fatty acids. It can also be associated that a lower induction period corresponds to lower levels of peroxide index.

Comparing the iodine index values with that reported by other authors López (2013) obtain 25,87gI2/goil, 24 gI2/goil, $22,22 \mathrm{gI} /$ goil and 23,44 $\mathrm{gI} /$ goil in the varieties Edward, Rosa, Lorito and Chancleto respectively. Likewise, higher values reported by the authors Silva (2018) and (Matos and Pirela 2014) are obtained, who obtained values of 43gI2/goil and 60,86 gI2/goil in the Kent and Pico de Loro variety. The Codex Stan 86-1981 of cocoa fat allows a minimum of 32g of iodine / $100 \mathrm{~g}$ fat or oil, and a maximum of $41 \mathrm{~g}$ of iodine / $100 \mathrm{~g}$ fat or oil. The iodine number relative to lipid unsaturation, a higher value indicates a higher unsaturated fatty acid content and generally reflects the lower slip melting point value due to such low melting fatty acids (Jin et al, 2018).

For the anisidine (AV) value, (Shahidi and Wanasundara 2008) explain that the obtained value is only comparable within each type of oil. For example, oils with high levels of polyunsaturated fatty acids can have a higher VA even when fresh. The p-anisidine assay measures the content of 
ISSNe: 2617-9156

aldehydes (predominantly 2-alkenals and 2, 4-dienals) that were formed due to decomposition of the hydro peroxides.

The peroxide number does not provide an accurate indication of the degree of oxidation. The p-anisidine value, therefore, added an additional dimension for the analysis of the oxidative stability of the oil (Nawab et al, 2018). Similarly, the Totox value is a very useful indicator in the deterioration of oils because it relates the history of the oil (anisidine index) with the current history (peroxide index) to determine the total degree of oxidation of the oil due to a primary and secondary oxidation where oxidative compounds such as peroxides and aldehydes are evaluated (Franco, 2014).

It is verify with the obtained results that the mango almond oils have the same tendency in all the oxidative rancidity evaluation tests, which indicates that the primary and secondary compounds are be generated simultaneously.

That is why only determining peroxides or anisidine is not a precision indicator of the oil oxidation state, since the peroxide index is limited to determining only the early oxidation reactions, while the anisidine index determines the volatile secondary products. (Lamas, 2014).

For the determination of total polyphenol content, the following equation $\mathrm{Y}=0,0369609 \mathrm{X}$ was considered, with a correlation coefficient of R2 $=0,999701$. The values of total amount of polyphenols reported in Table 3 coincide with that reported by Galvan (2015), which establishes that there is a progressive decrease in polyphenols in the oil. Same as the maturity of the fruit or seed from which the oil is extracted progresses.

This is evidence in the results of the degrees of maturity partially ripe and ripe. Brenes et al. (2000) also ensures that the concentration of total polyphenols in oil, determined by colorimetric methods, decreases with ripening, since a series of changes occur during ripening that affect the polyphenol profile.

Muñoz et al. (2013) also establishes that the variability in the polyphenol values depend on factors such as the type or variety of fruit, degree of ripeness, and other external factors such as agronomic, climatic conditions, oil extraction process, among other factors.

The phenolic content provides information about the nutritional quality, stability and sensory characteristics of the oil (Franco, 2014).

Muñoz et al. (2013) in their study establishes that there is a direct relationship in the antioxidant capacity and total polyphenols of the oil, which is verify by comparing the results obtained for each variety and degree of maturity, which is show in Table 3 . It is also observe regarding the results that in the first stages it is where there is more antioxidant activity.

Abdel et al. (2012) state that, due to both its phenolic compounds and antioxidant capacity, mango almond oil is show a good natural antioxidant because it slows down the oxidation of different edible vegetable oils, making mango seed a promising by-product of mango as a natural food additive to extend the shelf life of some food products.

Since mango almond, oil contains mostly unsaturated fatty acids, the presence of tocopherol, carotenoid pigments and phenolic compounds that are natural antioxidants in a vegetable oil make the oil more stable, delaying the oxidation of fatty acids (Galván, 2015).

Considering this bioactive potential, the development of ecological recovery strategies to obtain polyphenol-rich extracts of this valuable biological residue poses a great challenge and a unique opportunity for the mango processing industry to deliver a value-added product to the market with properties health promoters (Ballesteros - Vivas, 2019).

\section{Fatty Acid Profile}

According to the fatty acid profile obtained from the oils of mango almonds presented in Table 4, it is observe that the main fatty acids are obviously oleic.

Followed by stearic and palmitic which occupy more than $90 \%$ of the total. Demonstrating that mango oil is similar to other natural fats, and also the level of unsaturated fatty acids was approximately double that of saturated fatty acids, coinciding with what Torres-León et al (2016).

Their affirms that in addition an important advantage of the lipids of the almond of the mango seed is that it does not contain trans fatty acids, which are responsible for the development of various diseases and have various adverse effects on human health. Based on oleic acid, our results are higher than those reported by the following authors are López (2013), Tapia et al (2013), and Rodríguez (2014).

Their obtained values of $49,61 \%, 45,76 \%$ and $45,64 \%$ in the Edward, Kibangou and Mariquita varieties; and based on stearic acid, the results were lower than those reported by the following authors López (2013) and Rodríguez (2014) who obtained values of $34,81 \%$ and $36,57 \%$ in the Edward and Mariquita varieties.

Table 4.

Fatty acid profile of mango seed oil

\begin{tabular}{|c|c|c|c|}
\hline Variety & Degree of maturity & Fatty acid & Fatty acid profile (\%) \\
\hline \multirow{8}{*}{ Edward } & Partially ripe & Palmitic & $6,6695 \pm 0,2496^{*}$ \\
\hline & & Stearic & $33,9145 \pm 0,0106^{*}$ \\
\hline & & Oleic & $52,449 \pm 0,2701 *$ \\
\hline & & Linoleic & $5,7245 \pm 0,0064^{*}$ \\
\hline & & Arachidonic & $1,243 \pm 0,0028 *$ \\
\hline & Ripe & Palmitic & $5,4085 \pm 0,746^{*}$ \\
\hline & & Stearic & $32,1545 \pm 0,5042 *$ \\
\hline & & Oleic & $56,591 \pm 2,3335^{*}$ \\
\hline
\end{tabular}




\begin{tabular}{|c|c|c|c|}
\hline \multirow{12}{*}{ Kent } & \multirow{4}{*}{ Partially ripe } & & $5022+02071$ * \\
\hline & & Arachidonic & $\begin{array}{l}J, 205 \pm 0,20 / 1 \\
05625+07955^{2}\end{array}$ \\
\hline & & Palmitic & $10,813 \pm 5,2326^{*}$ \\
\hline & & Stearic & $27,156 \pm 2,769 *$ \\
\hline & \multirow{8}{*}{ Ripe } & Oleic & $53,285 \pm 3,5681 *$ \\
\hline & & Linoleic & $8,22 \pm 0,3606^{*}$ \\
\hline & & Arachidonic & $0,526 \pm 0,7439 *$ \\
\hline & & Palmitic & $7,437 \pm 0,1541^{*}$ \\
\hline & & Stearic & $28,213 \pm 0,1442 *$ \\
\hline & & Oleic & $54,7765 \pm 0,5636^{*}$ \\
\hline & & Linoleic & $8,3455 \pm 0,2312 *$ \\
\hline & & Arachidonic & $1,2285 \pm 0,0346^{*}$ \\
\hline
\end{tabular}

* Data expressed as mean \pm standard deviation of 2 replicates including 3 replicates each.

With the data obtained, the fatty acid content of mango seed oil differs show significantly depending on the variety in addition to latitude, geographic conditions and the degree of maturity at harvest.

López (2013) compared the fatty acid content of mango seed fat with cocoa fat, where differences were found, being the palmitic content higher in cocoa fat $(26,8 \%)$ and slightly lower oleic content (34,9\%). Consequently, mango seed oil is more stable than many other vegetable oils rich in unsaturated fatty acids. Such oils appear to be suitable for mixing with vegetable oils, manufacturing stearin, the confectionery industry, or the soap industry (Kittiphoom and Sutasinee 2013). For example, cocoa fat, which is the main component of chocolate and other confectionery products. There, TorresLeón et al (2016) reported that an equivalent of cocoa fat could be obtain from an $80 / 20$ mixture (percentage by weight) of mango seed almond fat and palm oil, being the fusion of mixtures in $85 / 15$ proportions, $80 / 20,75 / 25$ and $70 / 30$.

\section{Determination of the oxidative stability index}

It is observed in Table 5 that the values at a temperature of $130^{\circ} \mathrm{C}$ are high due to the composition of the almond oil of the mango seed that is rich in saturated and unsaturated fatty acids, such as stearic and oleic acid. It is content in total polyphenols and antioxidant capacity, which allows it to play an important role in protecting the human body and allows mango seed oil to be use in less stable oil mixtures for cooking and frying (Abdel et al., 2012).

The significance of the effect was determined using the $p$ value $(\mathrm{P}<0,05)$, where the lowest $\mathrm{p}$ value indicates the high significance of the coefficient, in this case the $p$ value indicates that the variety, the degree of maturity and the temperature are significant, which have a noticeable effect on the oxidative stability index. Therefore, having a $p$ value less than 0,05 shows that the variety, the degree of maturity and the temperature have a statistically significant effect on the oxidative stability index of mango seed oil with a $95 \%$ confidence level.

Table 5.

Oxidative stability index (OSI) of mango seed oil

\begin{tabular}{|c|c|c|c|c|c|}
\hline \multirow{2}{*}{ Variety } & \multirow{2}{*}{$\begin{array}{c}\text { Degree of } \\
\text { maturity }\end{array}$} & \multirow{2}{*}{ Flow } & \multicolumn{3}{|c|}{ Temperature $\left({ }^{\circ} \mathrm{C}\right)$} \\
\hline & & & $130 \mathrm{OSI} \pm \mathrm{SD}$ & $140 \mathrm{OSI} \pm \mathrm{SD}$ & $150 \mathrm{OSI} \pm \mathrm{SD}$ \\
\hline \multirow{2}{*}{ Edward } & Partially ripe & $15 \mathrm{~L} / \mathrm{h}$ & $16,14 \pm 0,4808 *$ & $6,755 \pm 0,1909 *$ & $3,06 \pm 0,0283^{*}$ \\
\hline & Ripe & $15 \mathrm{~L} / \mathrm{h}$ & $12,6 \pm 0 *$ & $6,145 \pm 0,0071^{*}$ & $2,88 \pm 0 *$ \\
\hline \multirow{2}{*}{ Kent } & Partially ripe & $15 \mathrm{~L} / \mathrm{h}$ & $14,96 \pm 0,7212^{*}$ & $6,21 \pm 0^{*}$ & $2,935 \pm 0,0071^{*}$ \\
\hline & Ripe & $15 \mathrm{~L} / \mathrm{h}$ & $12,375 \pm 0,1344^{*}$ & $5,81 \pm 0,2404^{*}$ & $2,685 \pm 0,0071 *$ \\
\hline
\end{tabular}

* Data expressed as mean \pm standard deviation of 2 replicates including 3 replicates each SD $=$ Standard deviation; OSI in hours.

Comparing the shelf-life values of table 6 mango seed oil with other vegetable oils such as avocado and sacha inchi oil that have shelf-life times of 2 years at $25^{\circ} \mathrm{C}$, and 1,79 years at $25^{\circ} \mathrm{C}$ respectively, the useful life values of this research are much higher, with a minimum of 4,35 years.

This difference may be due to the composition of fatty acids in each of the oils, since mango seed oil is characterized by having the typical behavior of a fat, being semi-solid at room temperature, since its content in saturated fatty acids (more than $30 \%$ ) is just as high as its unsaturated fatty acid content

Jin et al (2018) compared oxidative stability index results where a high value of $58,8-85,2 \mathrm{~h}\left(110^{\circ} \mathrm{C}\right.$, air flow $\left.20 \mathrm{~L} / \mathrm{h}\right)$ was obtained from mango seed oil, finding that the acid compositions Fatty and sterols (especially $\beta$-sitosterol) were the predominant compounds that affect the oxidative stability of the mentioned oil. 
Table 6 .

ISSNe: 2617-9156

Lifetime for mango seed oil at $20^{\circ} \mathrm{C}$

\begin{tabular}{ccc}
\hline Variety & Degree of maturity & Lifetime (years) \\
\hline \multirow{2}{*}{ Edward } & Partially ripe & 12,89 \\
& Ripe & 7,09 \\
\multirow{2}{*}{ Kent } & Partially ripe & 10,5 \\
& Ripe & 4,35 \\
\hline
\end{tabular}

This time were gives by the extrapolation graphs of the results of the oxidative stability index of the three degradation temperatures to which the oils were subjected.

\section{Conclusions}

Regarding the physicochemical characteristics of mango almond oil, there is a significant difference with a level of $95 \%$ confidence in the variables of variety and degree of maturity. A direct relationship are found in the degree of maturity and the characteristics of density, refractive index, acidity, iodine, peroxides, and anisidine. A mature degree of maturity presents a higher content of unsaturated fatty acids (oleic). Degree of maturity presents an inverse relationship with the content of total polyphenols, antioxidant capacity and oxidative stability. In the first stages there is the greatest antioxidant activity, the degree of maturity presents an inverse relationship with the content of total polyphenols, antioxidant capacity and oxidative stability. In the first stage there is the greatest antioxidant activity, in addition, it contains a higher content of total polyphenols and antioxidant capacity. Better preserves the oil, lengthening its useful life, as indicated by the oxidative stability data, presenting a useful lifetime with an OSI value of 12,89 , and based on the results of mango seed oil in both varieties and both degrees of maturity. It is show that they have great potential as raw materials for oil-based food products. Also as a natural antioxidant of functional foods, so it is suggest carrying out a feasibility study to determine if the production of mango seed oil on a large scale is profitable for the market. Besides, as well as it is recommended to make studies with the residual cake that originates in the oil extraction by means of the cold pressed method, and to evaluate its antioxidant capacity and the amount of polyphenols

\section{REFERENCES}

[1] Abdel, M; Ashoush, I; Nessrien, N. 2012. Characteristics of mango seed kernel butter and its effects on quality attributes of muffins. Alexandria Journal of Food Science and Technology, 9(2), 1-9.

[2] Abdelaziz, S. 2018. Physical chemical characteristics of mango kernel oil and meal. Middle East Journal of Applied Sciences, 8(1), 1-6.

[3] Ashoush, I; Gadallah, M. 2011. Utilization of mango peels and seed kernels powders as sources of phytochemicals in biscuit. World Journal of Dairy \& Food Sciences, 6 (1), 35-42.

[4] Bail, S; Stuebiger, G; Krist, S; Unterweger, H; Buch, G. 2008. Characterization of various grape seed oils by volatile compounds, triacylglycerol composition, total phenols and antioxidant capacity. Food Chemistry, 108(2008), 1122-1132 doi: 10.1016/j.foodchem. 2007.11.063.

[5] Ballesteros-Vivas, D; Álvarez-Rivera, G; Morante, SJ; Sánchez Camargo, AdP; Ibáñez, E; Parada-Alfonso, F; Cifuentes, A. 2019. An integrated approach for the valorization of mango seed kernel: Efficient extraction solvent selection, phytochemical profiling and antiproliferative activity assessment. Food Research International, $126, \quad 108616$ https://doi.org/10.1016/j.foodres.2019. 108616

[6] Brenes, M; García, A; García, P; Garrido, P. 2000. Rapid and complete extraction of phenols from olive oil and determination by means of a colometric electrode, array system. Journal of Agricultural and Food Chemistry, 48 (11), $5178-5183$.

[7] Culebro, C. 2017. Extracción de aceite de la semilla del mango Tommy Atkins. (Undergraduate thesis). Universidad de Ciencias y Artes de Chiapas, Chiapas, México.

[8] FAO, 2017. FAO Database. Recovered from: http://faostat3.fao.org. Access: 30.11.2018.

[9] Folin, O; Ciocalteu, V.1927. On tyrosine and tryptophan determinations in proteins. The journal of biological chemistry, 73(2), 627-650. Recovered http://www.jbc.org/content/73/2/627.full.pdf

[10] Franco, M. 2014. Influencia del estado de madurez del fruto sobre parámetros de calidad, compuestos fenólicos y propiedades antioxidantes de aceites de oliva vírgenes extremeños. Aprovechamiento de subproductos de almazara. (Doctoral thesis). Universidad de Extremadura, Badajoz, España.

[11] Galván, A. 2015. Influencia del índice de madurez y el tipo de envase en la estabilidad de las propiedades fisicoquímicas y sensoriales del aceite de oliva virgen de la variedad sevillana (Olea europea L.). (Undergraduate thesis). Universidad Nacional Jorge 
Basadre Grohmann. Tacna.

[12] Garrido, G ; Valdés, M. 2012. Avances en las investigaciones farmacológicas y toxicológicas con el extracto acuoso de la corteza del árbol de mango (Mangifera indica L.). Revista de la Sociedad de Farmacología de Chile, 5(2), 63-93.

[13] Guerrero, D; Farfán, R; Garrido, F; Ipanaqué, J; Yovera, L; Yovera, E. 2012. Diseño del proceso industrializado del mango en almíbar. Área Departamental de Ingeniería Industrial y de Sistemas, 1(3), 20-24. https://www.inei.gob.pe/prensa/noticias/produccionde-mango-se-incremento-en-648-8358/

[14] INEI, 2015. Producción de mango se incrementó en el Perú. Instituto Nacional de Estadística e Informática.

[15] Jahurul, M; Zaidul, I; Norulaini, N; Sahena, F; Abedin, M; Mohamed, A .2014. Hard cocoa butter replacers from mango seed fat and palm stearin. Food Chemistry. 154: 323-329.

[16] Jin, J; Jin, Q; Akoh, CC; Wang, X. 2018. Mango kernel fat fractions as potential healthy food ingredients: A review. Critical Reviews in Food Science and Nutrition, $1-8$.

[17] Jin, J; Ward, P; Mu, H; Zhang, Y; Jie, L; Mao, J; Wang, $X$. (2016). Characteristics of mango kernel fats extracted from 11 China-specific varieties and their typically fractionated fractions. Journal of the American Oil Chemists Society, 93(8), 1115-1125.

[18] Kittiphoom, S; Sutasinee, S. 2013. Mango seed, kernel oil and its physicochemical properties. International Food Research Journal, 20(3), 1145 - 1149.

[19] Lamas, D. 2014.Desgomado enzimático de aceites. (Doctoral thesis). Universidad nacional del Sur, Bahía Blanca, Argentina.

[20] Lieb, VM; Schuster, LK; Kronmüller, A; Schmarr, HG; Carle, R; Steingass, CB. 2018. Fatty acids, triacylglycerol, and thermal behavior of various mango (Mangifera indica L.) kernel fats. Food Research International, 116, 527-537.

[21] López, M.2013. Evaluación del rendimiento de extracción y caracterización de la grasa de semilla de 20 accesiones de mango del banco de germoplasma y materiales nativos. (Undergraduate thesis). Universidad de Tolima, Ibagué, Colombia.

[22] Masud, F; Meta, M; Amran, L; Zainal, Z. 2017. Physicochemical properties and fatty acid composition of mango seed kernel oil. International Journal of Engineering Sciences \& Research Technology, 7(1). IJESS7. doi: 10.5281/zenodo.1147523.
[23] Matos, M; Pirela, A. 2014. Comparación de las propiedades fisicoquímicas de los lípidos contenidos en la almendra de mango de los cultivares Tetenene y Pico de Loro. (Undergraduate thesis). Universidad Rafael Urdaneta, Maracaibo, Venezuela.

[24] Muchiri, D; Mahungu, S; Gituanja, S. 2012. Studies on mango (Mangifera indica, L.) kernel fat of some kenyan varieties in Meru. Journal of the American Oil Chemist's Society, 89(12), 1567 - 1575. doi: 10.1007/s11746-012-2054-6.

[25] Muñoz, A; Alvarado, C; Ramos, F; Castañeda, B; Barnett, E; Cárdenas, L; Yáñez, J; Cajaleón, D; Encina, C. 2013. Estudio de polifenoles, taninos y métodos químicos para determinar la actividad antioxidante de la semilla de Sacha Inchi (Plukenetia volubilis L). Revista Horizonte Médico, 13(1), 11-18.

[26] Nadeem, M; Imran, M; Khalique, A. 2016. Promising features of mango (Mangifera indica L.) kernel oil: a review. Journal of Food Science and Technology, 53(5), 2185-2195. doi:10.1007/s13197-015-2166-8.

[27] Nawab, A; Alam, F; Haq, MA; Lufti, Z; Hasnain, A. 2018. Effect of mango kernel, starch coatings on the shelf life of almond (Prunes dulcis) kernels. Journal of Food Processing and Preservation, 42: e13449. 1 -7. DOI: $10.1111 /$ jfpp.13449.

[28] Plank, D; Szpylka, J; Sapirstein, H; Woollard, D; Zapf, C; Lee, V; Chen, C; Liu, R; Tsao, R; Düsterloh, A; Baugh, S. 2012. Determination of antioxidant activity in foods and beverages by reaction with 2, 2' - Diphenyl 1 - Picrylhydrazyl (DPPH). Journal of AOAC International, 95(6), $1562-1569$. Doi: 10.5740/jaoacint.CS2012_04.

[29] Rodríguez, L. 2014.Efecto de tratamientos enzimático, microondas y ultrasonido en la extracción de grasa de semilla de mango (Mangifera indica L,). (Undergraduate thesis). Universidad de Tolima, Ibagué, Tolima. Colombia.

[30] Rojas, F; Burbano, F. 2011. Efecto de un pre tratamiento enzimático en el proceso de obtención de aceite de la semilla de mango. (Undergraduate thesis). Universidad del Valle, Santiago de Cali, Colombia.

[31] Shahidi, F; Wanasundara, U. 2008. Methods for measuring oxidative rancidity in fats and oils. Food Lipids Chemistry, Nutrition and Biotechnology, 88(3), 377-396. Doi: 10.1201/9781420046649.ch14.

[32] Sikdar, D; Hegde, S; Swamynathan, V; Varsha, S; Rakesh, R. 2017. Solvent extraction of mango (Mangifera indica L.) seed kernel and its characterization. International Journal of Engineering Sciences \& Research Technology, 5(4), 43-47. 
ISSNe: 2617-9156

[33] Silva, S. 2018. Extracción y caracterización de la grasa de almendra de mango (Mangifera indica L.) variedad Kent por prensa mecánica. (Undergraduate thesis). Universidad Nacional Agraria La Molina, Lima, Perú.

[34] Tapia, M; Pérez, B; Cavazos, J; Mayett, Y. 2013. Obtención de aceite de semilla de mango manila (Mangifera indica L.) como una alternativa para aprovechar subproductos agroindustriales en regiones tropicales. Revista mexicana de agro negocios, 32(17), $258-266$.

[35] Torres-León, C; Rojas, R; Contreras-Esquivel, JC; Serna-Cock, L; Belmares-Cerda, RE; Aguilar, CN. 2016. Mango seed: Functional and nutritional properties. Trends in Food Science \& Technology, 55, 109-117. doi: 10.1016/j.tifs.2016.06.009

[36] Villanueva, E; Castillo, D; Rodríguez, G. 2013. Influencia de los parámetros Rancimat sobre la determinación del índice de estabilidad oxidativa del aceite de Sesamum indicum L. Scientia Agropecuaria, $4(1), 173-180$.

[37] Zambrano, W; Martínez, J; Fernández, J. 2017. Determinación de la vida útil de la grasa de semilla de mango a diferentes temperaturas de almacenamiento. Revista Agrollanía. 14: 1 -5. 